ARTICLES

\title{
PERFICIO EMPTIONIS IN CASE OF A SALE OF WINE IN ROMAN LAW
}

\section{Petr Bělovský*}

\section{ABSTRACT}

Sale of things determined by weight, number or measure was regarded as a specific kind in Roman law. In order to establish an obligation, the object of sale had to be physically measured out, weighed or pointed out by counting. Still, it was debated among classical lawyers when exactly such a contract becomes perfect and thus binding for both contractual parties. The article attempts to pinpoint the moment of perficio emptionis of generic things, using the example of a sale of wine. Due to the character of such a thing, the sources mention a special set of rules for this kind of sale that require measuring out the wine sold (mensura) and contain an option to taste the wine (degustatio), as well as to spill out the wine sold (effundere vinum). All of these may be used in the analysis of the perficio emptionis as an indication of legal effects that take place at the moment of mensura and degustatio.

Keywords: Roman law; sale; generic things; wine; amphorae; dolia; perfection of sale; perficio emptionis; liability; mensura; degustatio; conditio

* Associate Professor of Roman law, Univerzita Karlova, Prague, Czech Republic, ORCID: 00000002-0774-3347. 
According to Gaius, there were special legal rules for the sale of those things quae pondere numero mensurave constant (which are determined by weight, number or measure), such as corn, wine, oil, silver, as well as for some "other things". ${ }^{1}$ One such characteristic that makes a sale of these kinds of things different is the moment when the contract is deemed perfect. Gaius mentions two ways in which generic goods, such as wine or oil, could be sold, namely: (1) by setting up a single overall price for the whole object, regardless of the amount, as for example "all the wine in my cellar", or "a hundred amphorae from my house" - this kind of sale being called per aversionem or uno pretio; or (2) by determining the price by unit, as for example "five sestercii for each pound", or with the clause in singulas libras quas adpenderis ("for every pound you weigh out"). ${ }^{2}$ In the first case, there is a regular sale, and therefore the contract is made when the parties reach consensus regarding the price and clearly specify the object. ${ }^{3}$ However, in the second case, when "wine was sold by the jar, oil by the gallon, corn by the peck, or silver by the pound", ${ }^{4}$ the sole agreement about the object and the price determined per unit was not enough; therefore, it did not have a legal effect.

In general, the Roman contract of emptio venditio was used primarily for the sale of individually determined items, namely things that were specific enough to become an object of a legal transaction. Yet, a purely generic uniform sale was unknown to Roman law. ${ }^{5}$ This is why an agreement to buy "a slave", "two pounds of silver" or "a hundred pounds of olives" without further specification, did not create any legal obligation. This might come as a surprise since grain, oil and wine were in fact three essential commodities of the Roman trade and market. It is clear from the sources that in order to create a legal effect, the agreement had to contain a provision regarding the quantity, measure or weight, and had to be followed by an act that de facto separated the specified goods from the whole. Let us observe the way Roman jurisprudence thought about the specific features of the sale of generic goods, using the example of the sale of wine. ${ }^{6}$

1 Gai D 18135 5; Inst 3, 14pr. Even though the term "generic thing" is not explicitly used in the sources and there is a reason to distinguish them from things quae pondere numero mensurave constant, for the purpose of this article we will refer to things determined by weight, number or measure simply as to generic things. The link between the two categories of res may be seen in Paul D 12121 .

2 Gai D 18135 5-7.

3 Ulp D 1812 1; Pomp D $1813 p r$; Ulp D $1819 p r$.

4 Gai D 18135 3: "Si vinum ita venierit, ut in singulas amphoras, item oleum, ut in singulos metretas, item frumentum, ut in singulos modios, item argentum, ut in singulas libras." (See trl by Watson The Digest of Justinian vol 1.)

$5 \quad$ See Zimmermann 1996: 236ff. This is why stipulatio was considered more appropriate for the sale of generic goods. See, also, Yaron 2004: 59ff.

6 As for generic sale, see Ernst 1997: 272. 
A number of questions were raised by classical lawyers, one of them being quando videatur emptio perfici, when does the sale become perfect? ${ }^{7}$ Gaius attempts to answer it by referring to the school of the Sabinians who held the view that the sale became perfect only once the generic object was physically measured out, weighed or pointed out by means of counting. This rule would also apply in some other cases, such as when a flock or herd of animals (universitas rerum), ${ }^{8}$ especially cattle, was sold. If the whole herd of cows should be sold for a single price, the contract was perfect at the moment of agreement. But if the price was fixed per beast (with the clause in singula corpora quae adnumeraveris), ${ }^{9}$ the contract was deemed perfect only when all the animals had been counted. The logic behind this statement was that both the price and the object of the sale had to be certain enough for the agreement to cause legal effect, and the measuring, weighing or counting was clearly a way for doing so. ${ }^{10}$ In other words, without measuring, weighing or counting it is not clear what exactly is being sold and what may be demanded by the actio empti.

In D 18135 7, Gaius again makes his point about the perficio emptionis in the case of generic objects by stating that the periculum passes only after the object had been measured out, regardless of whether the price was set per unit, or whether a lump sum was agreed for the whole. ${ }^{11}$ To explain this rule, Gaius uses wine as an example of a generic object of sale, and it is the sale of wine that we look into more closely, since the rules for the sale of wine are explained in the sources in detail, especially in the sixth title of Digest 18 De periculo et commodo rei venditae. ${ }^{12}$

Before we go any further, it needs to be said that in principle there were two ways in which wine was usually sold at the market of ancient Rome: in amphorae (vinum amphoriarum), or in dolia (sing dolium; also called seriae or cupae). ${ }^{13}$ Amphora is quite well known: a clay jar with a narrowed throat whose shape and size, with the capacity of approximately 26 liters, made them relatively easy to handle. Dolia, on the other hand, were large clay vessels that could contain up to 1000 liters of liquid or dry products and were usually two-thirds embedded in the ground and therefore not intended for transport or handling (although in some cases they were used on ships).

Better, and therefore more expensive wine, was usually sold directly in amphorae, while wine of poorer quality was stored in large dolia and sold in parts defined by quantity that was to be poured from the vessel according to an agreement. Storing wine after it was sold in amphorae was much easier, since every container was

Gai D 181355 .

8 Gai D 181356.

9 Gai D 18135 5. In a similar fashion, si grex venierit; see Gai D 181356.

10 On certainty of price in a conditional sale, see Thomas 1967: 77-89.

11 Gai D 181357.

12 See, also, D 33 6: "De tritico vino vel oleo legato".

13 When reading the sources, it is necessary to distinguish amphora as a vessel (approx. 26 liters) from amphora as a Roman unit for measuring liquids. 
secured against the penetration of air in order to minimise the risk of wine spoilage. Amphorae were usually carefully plugged and sealed with resin. ${ }^{14}$ Dolia, on the other hand, had a considerably wider throat that did not allow it to be closed that well, thus making it less resistant to the penetration of air. This is why vinum doliare changed its taste and quality much faster than vinum amphoriarum, and for this particular reason it became an important topic for Roman jurists. As storage containers, dolia were used repeatedly, while amphorae were usually sold together with its contents and were sometimes even specially designed for a particular customer. ${ }^{15}$

As for the terms used in legal sources, Iulianus makes it clear that the term vasa vinaria is used for wine-making vessels (for wine-pressing). Dolia were therefore considered to be wine containers only if the wine was stored in them, otherwise they may have had other uses (such as for the storage of grain). In a similar manner, amphorae were not considered to be wine containers either if they did not contain wine at a particular moment. ${ }^{16}$ Proculus states in this regard that the same applies to sale. Amphorae were therefore often considered an accessory to wine (akin to barrels) in case of sale, while the dolia in which the wine was stored were not: "Et scilicet id vendimus cum his amphoris et cadis: in dolia autem alia mente coicimus". ${ }^{17}$

In general, whether wine was sold by the whole dolia or by individual amphorae, the contract was made by consensus, as has namely just been explained..$^{18}$ The same was true when the wine was sold per aversionem, namely only a part of the wine contained in the dolia (that is, "half of the wine contained in your dolium") for a lump sum. However, the perfection of the sale was more complicated when the price for the vinum doliare was defined only per unit. The key moment for the transaction was the measuring of the agreed quantity of wine in the same manner as had been stated before regarding all generic goods. Due to the specific character of wine, Roman jurisprudence had made numerous points regarding this kind of sale. They focused namely on liability, especially for the periculum and the acor etmucor,${ }^{19} \mathrm{on}$ liability for the wine turning sour or for being spoilt after completion of the sale. ${ }^{20}$

14 See Dorrego, Carrera \& Luxan 2004: 369-374.

15 Also, in case of inheritance, Roman jurists debated whether the vessels are part of their contents; see Ulp D 3363 1. Ulpianus and Celsus agree that if wine is bequeathed, the amphorae in which the wine is stored are considered to be bequeathed as well - not because of their nature or purpose, but because there is an assumption that the testator wanted this to be so (voluerit accessioni esse vino amphoras). This was, however, not the case if the wine was contained in dolia.

16 Iul D 5016206

17 Procul D 33615.18

Gai D 181355 .

19 Recently Pennitz 1994: 251-296.

20 Liability for periculum is particularly important in case of the sale of wine due to biochemical processes that are typical for this food product. The quality of wine naturally changes with time and the speed of this process may depend on many factors, some of which may be influenced by the way the wine is stored and handled in the containers, while others may not. In legal terms we are therefore dealing with an object of sale that naturally changes over time and does it more rapidly than most other food commodities, such as grain or olive oil. 
In this article, however, we focus on the actual moment of perfecting the sale when vinum doliare was sold per unit. However, we use the remarks of classical lawyers concerning liability for acor et mucor in order to look into our topic, since liability is one of the indicators of a sale being perfect.

According to Ulpianus, in his commentary to Sabinus (D $1861 \mathrm{pr}$ ), if vinum doliare was sold and it went sour afterwards (just as when it got lost due to cracks in the wine containers), it was the buyer who was liable: "Si vinum venditum acuerit vel quid aliud vitii sustinuerit, emptoris erit damnum". ${ }^{21}$ This would, of course, be in accordance with the generally accepted rule of periculum est emptoris. ${ }^{22}$ The same view is confirmed by Gaius. ${ }^{23}$ However, the question remains when exactly wine as a generic object is considered to be sold, since only at that very moment may contractual liability be established. Gaius - in another fragment (D 18135 5) - states that the sale of generic things is made only after the wine had been measured out. In D 1861 1, Ulpianus confirms that "before measuring the wine, it is almost as though not yet sold" (priusquam admetiatur vinum, prope quasi nondum venit). He also says that the "wine is regarded as completely sold only when it has been tasted" (videlicet quasi tunc plenissime veneat, cum fuerit degustatum, D $1861 \mathrm{pr}$ ). How are we supposed to understand Ulpian's statement when he seems to indicate that the wine is sold even before it is measured out, when, according to Gaius, the measuring of the wine is necessary for the perfection of the sale? Ulpian once again confirms: "Custodiam ad diem mensurae venditor praestare debet" - even before the measuring takes place, the seller must take care of the wine, which means that there must be some legal effect given prior to the measuring, since without an obligation there can be no contractual liability. Clearly, by measuring, periculum passes to the buyer: "Post mensuram factam venditoris desinit esse periculum". ${ }^{24}$ But why does the seller have custodia even before the measuring takes place when there is no contract - that is, at least according to Gaius.

To find the answer, we should take a closer look at the two special elements of the sale of wine: the measuring (mensura) and the tasting (degustatio) of the wine sold. ${ }^{25}$

The word mensura signifies the actual division of the agreed quantity of wine from the whole contained in the particular dolium, regardless of whether it was done by the seller or buyer. The agreed amount of vinum doliare was poured from the dolium into amphorae or any other container as result of an obligation based on the contract established earlier. The buyer had an option to either carry away the purchased wine or to seal the dolium containing the wine and to keep it with the

21 Ulp D $1861 p r$.

22 Paul D 186 8pr: "Necessario sciendum est, quando perfecta sit emptio: tunc enim sciemus, cuius periculum sit: nam perfecta emptione periculum ad emptorem respiciet."

23 Gai D 18616.

24 Ulp D 18611.

25 On both elements, see Jakab 2009: $210 \mathrm{ff}$ and 227. 
seller until later. If the buyer had sealed the container with the wine sold (si dolium signatum sit ab emptore), while still at the seller's site, there was a difference in opinion among Roman lawyers about the legal effects of such an act. Trebatius understands the sealing of the containers by the buyer as an act by which the wine is delivered to him. Ulpianus, on the other hand, supports the view of Labeo who perceives the sealing only as a precaution against the wine turning sour or spoilt (accor et тисоr), providing that the actual delivery will only be done later. ${ }^{26}$ In other words, according to Trebatius the sealing of the barrels causes transfer of ownership, while according to Ulpian and Labeo, the seller remains the owner of the wine.

Gaius, in fact, shares the same view as Ulpianus as to the effects of measuring out the wine when he says that if part of the wine in dolia was sold, then until the wine had been measured out (antequam admetiatur), the risk remained on the seller (omne periculum ad venditorem pertinet).$^{27}$ It didn't matter whether a single price had been fixed for the whole amount, or the price had been set per unit. ${ }^{28}$ Even though Gaius talks about passing of the risk and not the perfection of the contract, we may assume that since he makes no explicit distinction between the sale uno pretio and the sale "per unit", he considers the sale to be perfect by the measuring, and not earlier. This view is confirmed also by Paulus, who states that the risk remains on the vendor until the wine had been measured: "Donec admetiatur omne periculum venditoris est". ${ }^{29}$

Another important indication of the sale of wine becoming perfect is the option of the seller to spill out the wine sold (effundere vinum) in case the buyer delays in collecting the wine sold from the seller..$^{30} \mathrm{He}$ is therefore given an option to destroy ${ }^{31}$ the object of sale even though the buyer has a contractual right to it. However, he was allowed to do so only si diem ad metiendum praestituit nec intra diem admensum est, if the date for measuring was set, but did not in fact take place within the specified period. Therefore, the right of the buyer to effundere vinum essentially depended on mensura, the measuring as well.

In view of Gaius' opinion as expressed in D 18135 , where he states that the sale of wine requires measuring out of the object of sale for the contract to be perfect, we are tempted to conclude that the seller is given the right to destroy the wine sold,

26 Ulp D 18612.

27 Gai D 181357 and Gai D 186 16: "Si quidem de bonitate eorum adfirmavit venditor". According to Ulp D 1861 1, prior to the measuring, the seller has custodia, while according to Gai 18135 7, he has periculum. Even though in the second fragment there is room for arguing that the seller remains liable due to the principle casum sentit dominus, Gaius still speaks of the liability of the seller.

28 Gai D 181357.

29 Paul D 1865.

30 See, recently, Hausmaninger 2001: 73ff; Jakab 1999: 73ff; Reetz 2015: 404ff.

31 See D 9227 15: "Effusum et acetum factum corrupti appellatione continentur". 
due to the simple fact that there is no contract where the generic object (wine) had not been measured out. If there is no contract without measuring, then the seller remains owner of the wine and he is therefore free to do whatever he would like to with his wine. However, the sources seem to indicate that this is in fact an issue of liability based on a contract, since we learn that licet venditori vel effundere vinum, ${ }^{32}$ the seller is "allowed" (licet) to spill the wine sold. There would not be a need to allow him to destroy the wine if he was the owner without any liability to a third person. Therefore, this again indicates that even before the measuring of the wine takes place, the agreement alone already imposes duties on the seller.

The procedure that followed after expiry of the date set up for measuring resembles that of regular mora. First of all, the seller had to call on the buyer again in order to collect the wine sold and to give him an explicit warning that would make him understand that if he failed to collect the wine, it could be spilled out by the seller. Such a warning had to be given in the presence of witnesses. In addition, the buyer may have charged rent for the containers in which the wine sold was stored, or he could have rented other containers for storing his own wine and charged the buyer for the costs of such storage. Alternatively, the seller may sell the wine to a third person and such sale is considered to be performed in good faith. With all the given options, however, Ulpianus recommends that the seller, if possible, uses the possibility to rent other containers and to keep the wine for the buyer as long as possible. This is in order to minimise the costs or potential damage that the buyer may incur - ut quam minime detrimento sit ea res emptori..$^{33}$ This statement again confirms that according to classical jurisprudence, the buyer must have had some kind of legal interest in the wine sold, even though it had not yet been measured out and it had not been delivered to him. In other words, the right of the seller to effundere vinum is yet another argument in support of the view that even before measuring the wine, the agreement between the seller and the buyer alone about the sale of wine per unit already causes some legal effect.

As we have seen, besides the measurement, another important moment in the sale of wine was degustatio. Ulpian states that it is difficult to believe that one would buy wine without having an option to taste it. ${ }^{34}$ According to Cato the Elder, the usual time for tasting was three days after the purchase: "In triduo proximo viri boni arbitratu degustato, si non ita fecerit, vinum pro degustato erit" ("after three days it was tasted by an honest man and if not, it was considered as tasted"). ${ }^{35}$ It appears that already in the second century $\mathrm{BC}$, it was customary to let the buyer taste the wine,

32 Ulp D 18613.

33 Eventually, if the seller is forced to pour out the wine, he should measure it beforehand to see how much damage the buyer will suffer. See Ulp D 1861 4: "Per corbem venditorem mensuram facere et effundere".

34 Ulp D 18641.

35 Cato De agricultura 157, 148. 
and the period given for such an option was "within a few days". What Cato also tells us here, is that the tasting of the wine sold went hand in hand with the actual delivery of the wine. And what is most important, according to custom, is that there was a presumption that after three days the wine was considered tasted, and thus delivered. We do not find any similar remarks about the length of the period for tasting in legal sources of the classical period, but Cato lets us assume that it was most probably set in days rather than in weeks. ${ }^{36}$

Degustatio was therefore an essential point in the sale of wine and in practice it played just as important a role as mensura. According to Ulpian, only degustatio finally completes the sale. ${ }^{37}$ Therefore, if the seller agreed to carry the risk for periculum he had to bear it until the agreed date or until the wine was tasted (fuerim degustatum). ${ }^{38}$ There was no strict deadline for tasting. If the parties agreed on a specific date for tasting and the buyer failed to taste it within the agreed period, the seller remained liable for periculum until the actual tasting. Therefore, if the tasting did not take place within the specified period of time without any fault on the part of the seller, he was relieved from liability for damage on the object of sale. ${ }^{39}$ As a result he was allowed to effundere vinum.

There was much discussion among scholars about the situation where the contract did not contain any provision about the degustatio. Yaron summarises the three most frequent opinions about the option to taste the wine in such a case: (a) the buyer had the option in any case, it was simply a custom; (b) the buyer had the option only if it was made part of the agreement; and (c) the buyer had the option to taste if not mentioned in the contract only in the case of vinum doliare, but not in the case of vinum amphorarium. ${ }^{40}$

Jakab points out (with reference to Ulpian and Cato) that, in fact, two types of tasting with two different types of legal effects should be distinguished when reading the sources - initial (anfängliche) and subsequent (nachträgliche). ${ }^{41}$ The "initial" degustatio (as in Ulp D $1864 \mathrm{pr}$ ) allowed the buyer to examine the purchased wine on a short-term basis (three days according to Cato) in order to check the quality that

36 See, also, Paterson 1982: 155.

37 Ulp D 18611 .

38 Ulp D 186 1pr: "Si vinum venditum acuerit vel quid aliud vitii sustinuerit, emptoris erit damnum, quemadmodum si vinum esset effusum vel vasis contusis vel qua alia ex causa. Sed si venditor se periculo subiecit, in id tempus periculum sustinebit, quoad se subiecit: quod si non designavit tempus, eatenus periculum sustinere debet, quoad degustetur vinum, videlicet quasi tunc plenissime veneat, cum fuerit degustatum." See, also, Yaron 1959: 71ff; Zimmermann 1996: 284ff; Frier 1983: 257ff.

39 Pomp D 186 18: "Cum moram emptor adhibere coepit, iam non culpam, sed dolum malum tantum praestandum a venditore"; Paul D 186 5: "Si per emptorem steterit, quo minus ad diem vinum tolleret, postea, nisi quod dolo malo venditoris interceptum esset, non debet ab eo praestari."

40 See Yaron 1959: 71.

41 Jakab 2009: 216, 221 and 225. 
was promised by the seller or at the auction. This was usually the case if the wine was not present when the sale was contracted. On the other hand, Jakab describes degustatio as "subsequent" if it constitutes part of the seller's long-term obligation if the wine remained stored with the seller after the sale and could change its quality in the course of time. The "initial" degustatio is the one that follows shortly after the perfection of the sale and the buyer is given the right to withdraw from the contract due to objective defects, while only "subsequent" degustatio was directly linked to the liability for acor et mucor and other possible defects depending on the agreement of the parties or commercial custom. ${ }^{42}$

In any case, degustatio in general allowed the customer to make sure that the wine did not acidify (acor) or is otherwise spoilt (mucor). However, in legal terms, the word degustat used in D 186 signifies an option based on the liability of the seller that the buyer received with perficio emptionis. Tasting was therefore not required for the contract to become perfect; on the contrary, the option to taste the wine could be given only with the perfection of the sale. The difference between measuring and tasting is clearly stated by Paulus (alia causa est degustandi, alia metiendi): "[T]asting is one thing, measuring out another, for tasting affords the possibility of rejection (improbare licet), while measuring serves ... to determine how much is being sold." ${ }^{33}$ Degustatio was therefore directly linked to liability for acor et mucor, while measuring finalised the agreement about the object of sale. If the parties reached the agreement about the sale, the tasting did not allow the buyer to refuse the wine simply because he did not like the taste of it anymore. However, it gave the buyer the option to refuse the wine sold in case the wine turned sour or otherwise got bad as a result of the seller's liability. Pomponius, referring to Proculus, says that even if the purchaser is willing to accept wine that had turned sour or bad after having agreed that he has an option to refuse it, he should not be compelled to do so. ${ }^{44}$

All that has just been discussed regarding the special character of the sale of vinum doliare when sold per unit leads us to the conclusion that such a sale was considered conditional. The tasting functioned as a conditio that was established by the agreement of the seller to remain liable for acor et mucor even after the completion of the sale, that is, after measuring out the wine.

The word quasi in D 18611 (priusquam admetiatur vinum, prope quasi nondum venit), as well as in D $1861 \mathrm{pr}$ (videlicet quasi tunc plenissime veneat, cum fuerit degustatum), when referring to the legal significance of mensura and degustatio, seems to confirm it. This is why Ulpian asks a rhetorical question - if someone sells wine and specifies a date by which it should be tasted and then prevents the tasting from taking place, is the sale null - emptio sit soluta? He attempts to answer: "Quasi

42 Idem at $225-226$.

43 D 181345.

44 Pomp D 1866. 
sub condicione venierint", it is as if it was conditional,${ }^{45}$ even though it depended on the agreement between the parties. But if there was none, the sale was deemed good (emptio manet) ${ }^{46}$ It is therefore clear that regardless of whether tasting takes place or not, the sale was deemed perfect and could place liability on the seller. Only a perfected sale would entitle the buyer to taste the wine. The tasting clause therefore functioned as a conditio resolutiva - the contract remains valid until the tasting is done - the contract is effective, but the result of the tasting may lead to an end to the contract. Degustatio therefore gives the buyer an option to reject the wine and to withdraw from the contract in case the wine turned sour, as is declared in D 18134 5. This explains why Ulpian considers wine to be "completely sold" (plenissime veneat) only once the tasting had taken place. He links tasting only to liability, which is possible only as a result of the contract becoming perfect. Therefore, the agreement on the degustatio is to be perceived as a conditio resolutiva casualis where acor or mucor causes the contract to be become void (see D 1866 ) regardless of the buyer's will. Consequently, the meeting of the condition is linked to the deterioration of the quality of the wine, not only to the act of degustation. On the other hand, the measuring out of the wine after the agreement may be regarded as conditio suspensiva potestativa ${ }^{47}$ which postponed the effects of the contract to the moment of measurement.

The effect the tasting clause had on the contract was therefore twofold: (1) the risk for periculum remained on the seller, and (2) it allowed the buyer to withdraw from the contract in case the wine sold turned sour. The main purpose of the tasting was therefore to confirm the sale.

It is clear, however, that what was said about some of the specific rules of the sale of wine does not concern other generic goods, such as oil or grain. Not only was there naturally no need for liability for acor et mисоr, but these goods did not change their quality over time as rapidly and therefore the clause about degustatio was unnecessary. On the other hand, mensura was always required in the sale of all goods quae pondere numero mensurave constant.

\section{Bibliography}

Dorrego, F, F Carrera \& MP Luxan (2004) "Investigations on Roman amphorae sealing systems" Materials and Structures 37: 369-374

Ernst, W (1997) “Gattungskauf und Lieferungskauf im römischen Recht” Zeitschrift der SavignyStiftung 114: 272-344

45 Ulp D 186 4; Jakab 2009: 220.

46 Ibid.

47 Gai D 181355 . 
Frier, B (1983) "Roman law and the wine trade: The problem of 'vinegar sold as wine"” Zeitschrift der Savigny-Stiftung 100: 257-295

Hausmaninger, H (2001) “The case of the deliberate wine spill” in J Cairns \& O Robinson (eds) Critical Studies in Ancient Law, Comparative Law and Legal History (Oxford): 73-78

Jakab, E (1999) “Vinum effundere in Ulp D 18613 ” in Zeitschrift der Savigny Stiftung 116: $71-111$

Jakab, E (2009) Risikomanagement beim Weinkauf: Periculum und Praxis im Imperium Romanum (München)

Paterson, J (1982) “'Salvation from the sea': Amphorae and trade in the Roman west" in $J$ of Roman Studies 72: 146-157

Pennitz, M (1994) “Die Gefahrtragung Beim Weinverkauf im Klassischen Römischen Recht” Revue d'Histoire du Droit 62(3): 251-296

Reetz, P (2015) “Mora creditoris im Römischen Recht” Revue d'Histoire du Droit 83(3-4): $392-420$

Thomas, JAC (1967) “Marginalia on certum pretium" Revue d'Histoire du Droit 35(1): 77-89

Yaron, R (1959) "Sale of wine" in D Daube (ed) Studies in the Roman Law of Sale: Dedicated to the Memory of Francis de Zulueta (Oxford): 71-77

Yaron, R (2004) "Remarks on consensual sale (with special attention to periculum emptoris)" Roman Legal Tradition 2: 59-76

Zimmermann, R (1996) The Law of Obligations: Roman Foundations of the Civilian Tradition (New York) 